\title{
ECOLOGICAL SECURITY: LEGAL CONCEPT, ATTRIBUTES, CRITERIA AND POSITION IN THE SYSTEM OF NATIONAL SECURITY
}

\section{Balyuk G., Kovalchuk T.}

\section{INTRODUCTION}

The legal basis of ecological security is recognized to be one of the critical prerequisites for maintaining livelihood of society. Ecological law must play an essential role in solving this daunting task with theoretical development of conceptual framework to be clearly understood both by ecological law theorists and practitioners. One of such cardinal concepts in this framework is 'ecological security'.

\section{Legal concept, attributes and criteria of ecological security}

A human being and nature. Our ancestors were sure of some mysticism in their coexistence and worshiped the elements of nature. Nowadays people, armed with scientific knowledge, believe they are the peak of nature and thoughtlessly waste its life force. Greenhouse effect, extinction of many plant and animal species, contaminated water and air have become reality of modern life.

$\mathrm{XX}$ century gave rise to the problems that concern not only single states or regions but humanity as a whole. The relationship between people and nature have become extremely aggravated. Throughout their history people have been using natural resources extensively, constantly mounting pressure on the environment.

The use of resources has dramatically changed the quality of life; however, economic growth aimed at quantitative factors has eventually resulted in large-scale environmental contamination and, in certain cases, has led to irreversible consequences, having changed the features of the Earth.

For a long time many states made economic strength and growth their chief priority, gaining it by any, sometimes dangerous, methods. Rapid industrialization and globalization processes continued until the second half of XX century when countries faced a challenge of limited natural resources, depletion of many of them and, as a result, inability to secure sustainable rates of economic growth in the long term. Ecological deterioration has been gradually turning into a planetary crisis encompassing different aspects of human life. The crisis has been caused by a number of factors: fast depletion of natural resources, environmental degradation, unfavorable demographic 
situation, poverty and starvation in many regions of the world, constant social conflicts, wars with mass destruction weapons, threat of international terrorism, etc.

So, humanity is living through complicated and contradictory times: on the one hand, everyone is interested in industrial and agricultural output growth, as well as in profit and gain. On the other hand, we tend to turn a blind eye to predatory, wasteful use of land, forests, water resources, poaching and nature extinction. But not any economic, technological or scientific accomplishment will make us happy if drinking water in Ukraine becomes unhealthy, if we breathe smog instead of clean air, if we consume food made of genetically modified plants.

However, the ecological situation both on the planetary scale of the Earth and in our country indicates that the industrial growth rates, increased anthropogenic impact on the environment, emergence of areas suffering from ecological disasters have put human life and health under threat. All this required the development of legal norms to grant security of a human in the process of environmental changes which later evolved as the institute of ecological security law and still later as one of the ecological law components - the ecological security law. As far as substantiation of ecological security law is concerned, the statement of V. Andreytsev seems to be relevant: "If one is doomed to Golgotha, it is not about protection but about salvation of the doomed one". Being a source of high insecurity, the environment, due to the activity of the natural elements or human-made catastrophe, turns into ecologically insecure object that requires 'isolation' from an individual and society, from other natural systems and complexes by establishing special legal mode that would limit or prohibit residence of people, social and private production activity, as well as would provide for carrying out measures to eliminate insecurity sources, establishing status of citizens who suffered due to insecurity ${ }^{1}$.

It should be noted that clear definition of the concept of ecological security, specifying its legal status as well as its criteria and threats to it, is not only of theoretical but also of great practical value. However, there is no single generally accepted viewpoint regarding the legal nature of 'ecological security' concept.

Today, there is a big number of approaches to define ecological security. Considering the ways of the concept definition, we should take into account the fact that the interdisciplinary scientific notion 'security' is in its basis.

1 Andreytsev V. Environmental Safety Law: Teaching and science-practical. tool / V.I. Andreytsev. K. : Znannya-Press, 2002. 332 p. 
It is worth mentioning, that security issues attracted attention of scholars since the time of Ancient Greece. According to "social contract theory" (Epicure, Spinoza, Diderot), the essential reason for state formation was accession to "the social contract" in order to overcome "the natural state of the war of all against all", and the main goal of a state is to ensure security of both society and an individual ${ }^{2}$.

During monarch reign this concept involved ensuring security of a monarch, ruling class and monarchy itself. But at the beginning of Renaissance and Enlightment a man (a citizen) - society (a political nation) - a state were considered as the objects of security. At the same time, a state was regarded as the subject of security. The issues of security and survival, the structure of relationship between government, population and state, committed to secure welfare and protection from external threats, were considered in the works of outstanding scholars of Renaissance, N. Machiavelli ("The Prince") and T. Hobbes ("Leviathan") in particular, laying grounds for modern theory of state as well as for political science as a whole. Security was defined as "the means of collective protection" in the war of "all against all" and considered to be the basis of state. In other words, security ensured by state was believed to be the prerequisite for survival and development of an individual as a "human being civilized by the threat of death" ${ }^{3}$.

The role of law and state in providing security of an individual and society was considered in I. Kant "Perpetual Peace" and G. Hegel "Philosophy of History", "Philosophy of Law". The issues of internal and external security were developed in works of Montesquieu, Bentham, Burke, Lipinski, Dontsov and other ${ }^{4}$.

Summarizing philosophical approaches to the term 'security', we can arrive at a conclusion that its definition is always related to the notion of 'state' - that is a category of scientific learning attributed with the capacity of moving matter to manifest itself in different forms with specific features and relationships ${ }^{5}$. Security is considered to be a state of being protected, lack of different kinds of threats.

${ }^{2}$ Skakun O. Theory of State and Law: textbook / O.Skakun: trans. from Rus. Kharkiv: Consum, 2001. $656 \mathrm{p}$.

${ }^{3}$ National Security of Ukraine: History and Present / Ed. O. Goncharenko. K., 1993. 82 p.

4 Yurkevich Pamphil. History of Philosophy of Law. Philosophy of Law / Pamphil Jurkevich // Philosophical Diary. $2^{\text {nd }}$ ed. K. : Editorial in the magazine "Ukrainian World", 2000. 769 p.

${ }^{5}$ Philosophical Encyclopedic Dictionary / [Ed.: S. Averintsev, E. Arab-Ogly, L. Ilyichev et al.]. 2nd ed. M. : Soviet Encyclopedia. 1989. 815 p. 
Similar definition can be found in reference sources where security is viewed as lack of threats to an object from internal or external factors ${ }^{6}$. Depending on the origin of a threat, the nature of its emergence, there is differentiation of threats into ecological, economic, political, military security, etc. Security is assumed to be an indispensable feature of any system, which, in its turn, is reflected in such systemic characteristics as integrity, relative independence and constancy ${ }^{7}$.

It is to be noted that there are two principal approaches to definition of a legal concept of ecological security.

Within the first one ecological security is understood as a certain state. G. Serov in particular, defines ecological security as a condition when the vital interests of an individual, society and state are protected from threats:

a) coming from natural objects whose features have changed due to pollution, littering related to anthropogenic activity (occurrence of accidents, catastrophes, durable business, military and other kinds of activity) or have been changed intentionally by environmental diversion, aggression or natural phenomena and disasters, b) caused by destruction, damage or depletion of natural resources (the threat of non-provision of community and state with natural resources) $)^{8}$.

M. Vedenin gives definition of ecological security as a state of protection of an individual, society, state and environment from adverse natural and technogenic impact that is secured by legal, economic, scientific, technological and other means and ways ${ }^{9}$.

Ecological security is also considered to be a state when all environmental components due to the balance of reciprocal impacts of natural, technological and social systems and the formation of natural and cultural environment are optimal for normal functioning and development of human civilization ${ }^{10}$.

In the field of economics 'ecological security' is defined with regard to its role in economic development of a country. Therefore, there is a viewpoint that this is a certain state understood as adequacy of ecological conditions to

\footnotetext{
${ }^{6}$ Great Interpretative Dictionary of Modern Ukrainian / [ed. By V. Busel.]. K. : Irpin. Perun. 2002. 1440 p.

${ }^{7}$ Lapina M. Ensuring of environmental security by law enforcement agencies: foreign experience: monograph / M.A. Lapina. M. : VNII Ministry of Internal Affairs of Russia, 2001. $115 \mathrm{p}$.

${ }^{8}$ Serov G. Legal regulation of issues of environmental security in industrial and other activities / G. Serov. Moscow: Os-89, 1998. 222 p.

${ }^{9}$ Vedenin N. Environmental Law: Textbook. [for university students ] / Vedenin N.N. M. : Law. 2000. P. 20.

${ }^{10}$ Mahmud A.A. Environmental safety as a subject of international cooperation policy: $\mathrm{PhD}$ reference paper: 23.00.02 / A.A. Mahmoud: Inst. Of State and Law. V.M. Koretskiy NASU. K., 2000. 24 p.
} 
the objectives of preserving health of population and securing sustainable social and economic development ${ }^{11}$.

Proceeding from this definition, we can express ecological security as a monetary value. In case of non- compliance with ecological standards, the environmental quality degrades and there arises the need to somehow compensate its negative impact on people's health as well as on production sector (e.g. agriculture). Compensation measures, in their turn, require appropriate funding. In addition, duration, scale and intensity of ecological insecurity factors may increase the necessary amount. All these make up the cost of ecological security for a state and entrepreneurial entities. For an individual the cost includes spending on healthcare service, on installation of additional air and water purification devices, etc. Considering this, ecological security is held to be an economic value which has its monetary value ${ }^{12}$. The need for development of ecologically safe production, including produce for export, is substantiated and supported by facts of popularity of clean organic products worldwide and in developed countries, in particular, as well as by emergence of certain 'ecological phobia'.

Other sources reveal the content of ecological security relating it to national ecological interest ${ }^{13}$ or the interest in the sphere of ecological security ${ }^{14}$, meaning integrated state interests which determine the policy in the field of ecological security.

The most comprehensive definition of ecological security concept, in our opinion, was offered by V. Andreytsev. He believes that ecological security as a category of law is a component of national and transnational security, that is taken to be such state of development of social and legal relationships when legal norms system as well as other state and social means secure the right of citizens to safe for life and health environment, provide for regulation of activities hazardous for environment, prevent environmental degradation as well as other consequences which may be dangerous for life and health of an individual, society and state and that requires clear constitutionalization in the effective law ${ }^{15}$.

11 Economy, freedom, solidarity. [G. Hofman, V. Demetyev, N.Fedorenko M. : Nauka, 1991. 304 p.

12 Economy, freedom, solidarity. [G. Hofman, V. Demetyev, N. Fedorenko M. : Nauka, 1991. 304 p.

${ }^{13}$ Khlobystov EV Ecological security of transformation economy / E. Khlobystov: RVPS of Ukraine of NAS of Ukraine. K. : Chornobylinterinform Agency. 2004. 336 p.

${ }^{14}$ Kachinsky A., Khmil G. Ecological security of Ukraine: analysis, forecast, evaluation and state policy / A. Kachinsky, G.Khmil. K. : NISD, 1997. 130 p.

15 Andreytsev V. Environmental Safety Law: Teaching and science-practical. tool / V.I. Andreytsev. K. : Znannya-Press, 2002. 332 p. 
The second approach to definition of ecological security is understanding it as a certain activity. Researching issues of ecological security, M. Malyshko considers it as a system of measures aimed at protection of vital interests of an individual from adverse environmental impact. Meanwhile he rightly notes that ecological security is a focal issue of human ecology, since a human being, its interests and eco fund are direct objects of protection ${ }^{16}$. However, this definition does not take into account the impact of technogenic factors and the possibility of such impact coming from modified environment cannot be excluded.

In opinion of S. Bogolyubov, ecological security is the process of ensuring security of vital interests of an individual, society, nature and state from actual and potential threats, caused by anthropogenic and natural impact on the environment.

A great number of approaches to definition of ecological security concept mentioned above brings about legal issues related to determining the field of law the concept belongs to, and this uncertainty, in its turn, does not enable to define the unified concept 'ecological security'. So, we are confronted with a peculiar 'vicious circle'. In our opinion, the first approach, relating the content of ecological security to a certain state, is correct, since ecological security is both a goal and a task for activity of all stakeholders, though the process of ensuring security or activity in this sphere does not still guarantee a result. In addition, law-makers also relate ecological security to a state.

Taking into consideration the approaches mentioned above, we can arrive at a conclusion that ecological security as a category of law should be regarded as security of vital interests of an individual, society, state and environment, which guarantees the right of every individual to healthy and safe environment and provides all necessary conditions for environmental protection, reproduction of natural resources and exercising other rights of citizens as well as interests of the state.

So, the notion 'ecological security' is a hyponym of a broader concept 'security' originating from Latin securitas meaning "condition of being secure" and is considered a component and a prerequisite for national and international security. According to the Law of Ukraine "On National Security of Ukraine" of June 21, 2018, national security means protection of state sovereignty, territorial integrity, democratic constitutional order and other national interests from actual and potential threats ${ }^{17}$.

16 Malyshko MI Environmental Law of Ukraine: Educ. tool. K. : Yuridichna Kniga Publishing, 2001. 389 p.

${ }^{17}$ Law of Ukraine "On National Security of Ukraine" of 21 June 2018 // Verkhovna Rada of Ukraine Bulletin, 2018, No. 31, Art. 241. 
The Law of Ukraine "On Environmental Protection" treats ecological security as "the environmental state that provides prevention of ecological degradation or emergence of insecurity for people's health" (Article50) ${ }^{18}$. It is clear that definition of ecological security is at a number of points different from general definition of national security. The first points out the necessity to prevent ecological hazards, while the second notes not only prevention but also detection and mitigation of actual and potential threats to national interests, including ecological threats.

The State Standard of Ukraine "Security of industrial plants. Terms and definitions" gives the definition different from legislative formula of ecological security provided by the Law of Ukraine "On Environmental Protection". The standard defines security of population, material projects and environment as lack of unacceptable risk related to possibility of causing any damage. In reference addendum to the standard ecological security is inferred from lack of actions, states or processes which directly or indirectly lead to considerable damage to environment, population and material objects ${ }^{19}$.

The definition quoted above formulates the attributes of ecological security relating them primarily to lack of unacceptable risk. The standard actually proceeds from the concept of ecological security, the core of which is the theory of ecological risk ${ }^{20}$ (theory of lack of actual and potential threats).

Naturally, the question arises: what kind of notion that is so frequently used in different fields of law ecological risk is. As a matter of fact, different definitions can be found in different fields. The notion of risk came to ecological law, ecological legislation and practice from mathematics, statistics, probability theory of games, theory of decision making. Recommendations of international organizations (e.g. of the International Commission on Radiological Protection - ICRP) were of considerable importance for understanding, adopting and using this term.

In encyclopedic sources the category of risk is considered as probability of occurrence of undesirable events and consequences ${ }^{21}$. In this context the notion of risk is definitely related to occurrence of unpredictable events and adverse consequences that have subjective meaning for unlimited number of people.

\footnotetext{
${ }^{18}$ Law of Ukraine "On Environmental Protection" of June 25, 1991. The Verkhovna Rada of Ukraine Bulletin, 1991, No.41, Art. 546.

19 State standard of Ukraine. Safety of industrial enterprises. Terms and definitions. DSTU 2156-93. K., 1994.

${ }^{20}$ Environmental risk and national security // Economy. Entrepreneurship. The environment. 1994. № 1. S. 20.

${ }^{21}$ Interpretive Dictionary of Metrology, Measurement Engineering and Quality Management: Basic Terms. M., 1990.
} 
Legal definition of risk can be found in the Law of Ukraine 'On High Risk Objects' of January 18, 2001, according to which risk is probability degree of a certain adverse event that can occur at a certain time or under certain circumstances on the territory of high risk object or beyond $\mathrm{it}^{22}$.

One of the state standards defines risk as probability of adverse consequences from total negative impacts on the environment which cause irreversible ecosystem degradation ${ }^{23}$. Unfortunately, there is no mentioning of an individual, its life and health in this definition.

So, ecological risk is held to be a type of general category of risk and an attribute of ecological insecurity or activity hazardous for ecology. It reflects objective essence of such activity, i.e. probability of insecurity occurrence. The Cabinet of Ministers resolution of 28.08.2013 specifies the list of high ecological risk activities and dangerous objects. It outlines, in particular, the activities which cause such a degree of risk that involves certain legal consequences related to a) subject side of the legal structure, i.e. the duty to foresee and outline preventive measures, and b) object side when specified and permitted activities involve special risk or when particular activity is permitted since it is useful for society and has no alternative at the time. This can be exemplified by the activities related to the use of nuclear energy properties.

Today the regulatory framework of Ukraine specifies the principal types of risky activities and corresponding objects, posing high ecological risk: operations of nuclear power plants, chemical, petrochemical and recycling businesses; biochemical, biotechnological and pharmaceutical production, businesses involved in neutralization, utilization and other kinds of industrial and household waste management, etc. It also provides for the possibility to include here other kinds of activity, other production facilities and processes that may have hazardous impact on environment. Depending on their nature, specifics of physical, chemical and biological composition of used substances, ecologically dangerous activities pose different degrees of ecological risk.

Consequently, ecological risk sources are considered to be environmental activities which, as a rule, are authorized, since in case of unauthorized activity it is due to be stopped without risk assessment, by its presumption. Risk carriers are a number of objects and different substances of natural and artificial origin which under certain natural and social conditions can exhibit properties threatening to human health and life as well as to the world. It

${ }^{22}$ Law of Ukraine "On Objects of High Danger" of January 18, 2001. 73; 2003, No. 30, Art. 247.

23 State standard of Ukraine. Safety of industrial enterprises. Terms and definitions. DSTU 2156-93. K., 1994. 
should also be noted that certain natural phenomena may be sources of danger for a man, society and environment (floods, hurricanes, volcanoes, etc.).

Taking into account that ecologically hazardous activities, objects, substances and their combinations pose high ecological risk, their operations and usage are subject to special regulation, to legal regulation in particular. In other words, legal measures of ecological risk management prove to be necessary. These include the ways of influencing the entities carrying out ecologically dangerous activities which implies application of law norms and realization of legal potential by means of a) assessment of planned activity impact on the environment; b) procedure for making and coordinating ecologically meaningful decisions; c) licensing the activities related to use of sources posing risk to environment, life and health of people; d) submitting security declaration of increased risk object; e) risk insurance; f) certification; g) application of legal liability, etc.

In this respect, legal relationships in the field of ensuring ecological security are recognized as absolute, since citizens possess the absolute right to ecological security that corresponds to the duty of state, legal and physical entities to ensure execution of a number of mandatory requirements concerning ecological security. In this way, for the latter the right to ecological risk is transformed into obligation to take actions aimed at preventing occurrence of ecological insecurity (as manifestation of ecological risk) or eliminating consequences of such insecurity by means of risk aversion or mitigation.

Therefore, a set of conditions and legally fixed actions regarding implementing the procedure of licensing the ecologically insecure types of activities and issuing corresponding permits comprise a certain legal structure as the ground for legal relationship in the field of ecological security. Under certain circumstances, the legal structure can be supplemented by additional actions (legal facts), which prove to be important for emergence of legal relationships in the field of ecological security.

At the same time, there may be other grounds for legal relationship in the field of ecological security, especially when it comes to the universal human right of citizens to natural security. The right is based on risk related to various natural phenomena. The basis for emergence of this set of legal relationship is a number of legal norms that recognize ecological security and maintaining ecological balance on the territory of Ukraine a duty of the state (Constitution of Ukraine, Article 16).

The subjects of legal relations in the field of ecological security are the citizens of Ukraine, natural and legal persons, the state.

The objects of legal relations, mentioned above, are life and health of people, safe natural environment and its elements (natural conditions). 
Therefore, analysis of the effective legislation, professional legal and reference literature enables us to identify significant legal attributes of the concept 'ecological security'. The first one is that ecological security is the subject matter of ecological law, a component of national and transnational security. The second one manifests itself in available system of state-legal and other social means to prevent emergence of various threats through regulation of activities posing ecological risk. The third one refers to the focus of ecological security system in the area of environmentally risky types of activity or natural disasters, capable to bring the state of environment to the level that is dangerous for health and life of people as well as for society and state. The fourth attribute of ecological security is essentially associated with prevention of environmentally risky activities, conditions and processes, that is, with preventive measures.

\section{Ecological security in the system of national security of Ukraine}

Studies of the position and role of ecological security in the system of national security of the state have certain history. Research began at the end of $\mathrm{XX}$ century when awareness of state independence required methodological support to formation of national security policy, study of national security fundamentals as a systemic multicomponent phenomenon and one of the basic principles of state formation. Therefore, consideration of the position of ecological security in current situation of formation of national strategy and balanced policy of sustainable economic, ecological and social development is believed to be an urgent scientific and practical task.

The importance of investigating the place of ecological security in the national security system is related to necessity of analysis, prevention and forecasting of natural and man-made emergencies characterized by constant increase in material costs and social losses. Today, the nature of emergencies has begun to change dramatically, hazards and threats are more interconnected, their research is increasingly becoming interdisciplinary plane. The risk of natural disasters is increasing due to anthropogenic activity, which is the underlying cause for many natural disasters that have occurred in Ukraine recently. These include catastrophic floods in Transcarpathia, uncontrolled deforestation, landslide in mining and high urbanization sites, the phenomenon of man-made seismicity in many regions of Ukraine, etc.

"The Main Principles (Strategy) of State Ecological policy of Ukraine for the Period up to 2030", approved by the Law of Ukraine of February 28, $2019^{24}$, outlined the main problems for the state of ecological security of Ukraine.

${ }^{24}$ Law of Ukraine "The Main Principles (Strategy) of State Ecological policy of Ukraine for the Period up to 2030" of February 28, 2019. Verkhovna Rada of Ukraine Bulletin, 2019, No. 16, Art. 70 . 
Deterioration of atmospheric air quality. One of the reasons that cause poor air quality in the settlements and concentration of greenhouse gases in the atmosphere is non-compliance of economic entities with ecological legislation norms and low rates of implementation of advanced technologies. In order to improve the quality of atmospheric air and strengthen response to climate change and to achieve the aim of sustainable low carbon development in all sectors of economy, Ukraine must enforce ratified international documents on counteraction to climatic change and ambient air improvement.

Climate change. At the beginning of XXI century climate change was recognized by the world community as one of major problems of the global development with potentially serious threats to global economy and international security due to direct and indirect risks related to energy security, provision of food and drinking water, ecosystem sustainability, risks to human health and life. According to the Paris Agreement, Ukraine, as a party to the agreement, is obliged to make its nationally defined contribution to achieve the goal of sustainable low carbon development in all sectors of economy and to increase its capacity to adapt to the unfavorable climate change effects, in particular by decreasing total greenhouse gases emission.

Problems in the sphere of water protection. Ukraine is one of the European countries having the least water supply. Due to toxic, microbiologic and biogenic pollution, the ecological state of river basins, as well as of coastal waters and territorial waters of the Black Sea and the Azov Sea is deteriorating. The current water monitoring system in Ukraine is inefficient and outdated, does not meet current European standards. The system of public administration in water protection sphere requires reformation and transition to actual, not formal, integrated management of water resources by the basin principle.

Problems in the field of protection of land and soils. The current use of land resources of Ukraine does not meet the requirements of rational use of nature. The state of land resources of Ukraine is close to critical.

The reasons for such situation are complex and have historical background. Especially noteworthy is the violation of ecologically balanced ratio between land categories, the reduction of unique steppe areas, excessive plowing of territories and the violation of processes of natural soil formation, the use of imperfect technologies in agriculture, industry, power sector, transport and other sectors of the economy, aiming at gaining short and medium-term economic benefits while ignoring the environment preservation component.

Problems in the field of forest protection. The main causes of problems in the forest area are the imperfection of the forest management and forestry development, the lack of legal and economic mechanisms as well as the 
incentives for introduction of conservation technologies, the imperfection of the tax base and the unclear definition of the legal regime for management of lands sheltered with forest belts.

Issues in the field of use and protection of subsoil. There are systemic problems in the area of subsoil use in Ukraine, which pose a real threat to the economic security of the state. In Ukraine, which is 0.4 percent of the planet's land surface, up to five percent of all mineral resources of the globe have been discovered. The country possesses more than 20 thousand deposits and ores of 95 types of minerals, of which about 8 thousand are of industrial importance and are accounted for by the State Balance of Minerals. The total number of developed fields is about three thousand. At the same time, inefficient public administration in this area, lack of investment, use of obsolete equipment by mining companies, depreciated to 70 percent, and the outflow of qualified specialists have led to poor quality of industry performance.

The transition to resource-saving technologies, the full implementation of environmental impact assessment, the obligatory reclamation and inevitable responsibility for violations of the environmental legislation should be the main directions of balanced use of Ukrainian subsoil.

Emergency risk. On the territory of Ukraine there is a high risk of natural and man-made emergencies, the main reasons being: obsolescence of fixed assets, in particular those designed for environmental protection; large volume of transportation, storage and use of hazardous substances, emergency condition of a large part of public utility networks, insufficient investments into introduction of environmentally friendly, resource- and energy-saving technologies, especially in metallurgical, chemical, petrochemical industries and power sector; significant changes in the state of the geological environment due to the closure of unprofitable mining enterprises; the hydrogeological regime of water bodies; the reluctance of economic entities to take measures to prevent accidents and catastrophes at high risk sites and potentially dangerous objects, etc.

On the territory of the exclusion zone and the zone of unconditional (compulsory) resettlement there are objects of the State specialized enterprise "Chornobyl NPP", which require their decommissioning and putting into ecologically safe state, and objects of the system of radiation-ecological control and radiation monitoring of the environment condition and the provision of radiation safety.

Ecological problems of Donbass. Hostilities, destruction of infrastructure and of environmentally hazardous enterprises on the temporarily occupied territory of Ukraine have upset the ecological balance, which has led to dangerous changes in the environment, caused harm to health and violated the life safety for five million people in the area of about 30 thousand square kilometers. 
The main threats are: flooding of mines and the possibility of toxic mine water coming to the surface, infiltration into groundwater; threat of its running into the river Seversky Donets and the Sea of Azov; termination of operation of treatment facilities and damage to toxic and radioactive waste storage facilities; damage to the territories of the nature reserve fund; atmospheric air and soil contamination by chemical products due to ammunition explosions; the destruction of landscape and vegetation in connection with the use of military equipment and the construction of defense structures; the destruction of large areas of forests as a result of warfare and uncontrolled deforestation.

Environmental monitoring of the Donetsk and Luhansk regions, where government bodies temporarily do not exercise their authority, with the possible engagement of international environmental experts to assess the ecological situation, is becoming increasingly urgent.

Problems with waste management. Unlike European countries, Ukraine has a very low level of solid waste recycling and disposal and a high landfill level. Much of the landfill is overloaded and does not meet environmental and sanitary standards.

A significant threat to the environment and human health is the waste generated in the process of medical care, processing of raw materials of animal origin, pharmacological and cosmetic industries containing dangerous pathogenic and conditionally pathogenic microorganisms, as well as electrical and electronic equipment wastes.

The underlying reason for this situation is the imperfect legal framework, the lack of an efficient accounting and reporting system, and a monitoring system in the field of waste management.

Solving this problem is key to energy and resource independence of the state, saving natural material and energy resources, and is also the task of state environmental policy.

Problems in the field of biosafety. Priorities of the state policy in the field of biological security and biological protection are implementation of systematic measures for creation and effective functioning of the national system of biological security and biological protection, counteraction to acts of bioterrorism, protection of the population against the uncontrolled and unlawful spread of genetically modified organisms, preservation of safe for human health state of the environment, creating an early detection and fast response system to prevent the spread of pathogens of especially dangerous diseases and those of international importance, as well as improving the logistics of laboratories, establishments and institutions carrying out diagnostics of infectious diseases, monitoring of laboratories which work with pathogens of especially dangerous infectious diseases, determining their 
impact on the environment, in particular on biodiversity, with account of the risks to human health; creation of a system of rapid response to the manifestations of bioterrorism.

Threats to biological and landscape diversity. Occupying less than 6 percent of Europe's area, Ukraine owns about 35 percent of its biodiversity. The biosphere of Ukraine has more than 70 thousand species of flora and fauna, in particular flora - more than 27 thousand species, fauna more than 45 thousand species. In recent years there has been an increase in the number of plant and animal species included in the Red Data Book of Ukraine.

The main threat to biodiversity comes from human activities and the destruction of the natural habitat of flora and fauna. There is a catastrophic decrease in the area of wetlands, steppe ecosystems, natural forests, which is caused by land plowing, deforestation with a further change of land use purpose, drainage or hydration of territories, industrial, residential and holiday home construction, etc. The spread of non-native species in natural ecosystems causes considerable imbalance in biocenoses.

In order to curb biodiversity loss, Ukraine should take into account the recommendations of international documents on the revision and updating of legislation and standard acts on biological diversity.

Ukraine, like any other sovereign state, is building its own national security system. Recently, for Ukraine, this problem has become urgent due to both fundamental changes in the basic values of internal development and changes in the external environment. In particular, this is about:

1) transformation of socio-economic model of development from administrative-command to market and democratic political system;

2) positive and negative effects of the proposed reforms;

3) dismantling international and European security systems;

4) aggressive policy of the Russian Federation against Ukraine (annexation of the Crimea, waging a "hybrid war" in the east of Ukraine, diversions throughout Ukraine, evil anti-Ukrainian information propaganda among the population of Russia, Ukraine, and the entire world community in order to achieve geopolitical strategic revenge of "the Russian world";

5) increasing threats of a global nature (depletion of natural resources, pollution of the environment, etc.).

The above forces constantly identify and timely assess the real and potential threats to Ukraine's security in order to identify specific ways and means of preventing them. Ukraine's national security is directly linked to the determination of its national interests, which reflect the higher interests of society and the citizen. 


\section{CONCLUSIONS}

In terms of a global approach to security, any aspect that threatens the survival of the planet and its nature must be considered a security threat. Death from a nuclear disaster and death from air shortage is still death. The pace of the global changes, mentioned above, is much higher than it was previously predicted by scientists. If these processes remain uncontrolled, they will become irreversible.

Environmental problems are problems of completely new dimensions. Even with unlimited resources, it is impossible to recover the ozone layer or to "seal the ozone hole". Global warming cannot be stopped if its causes are not eliminated. The disparities in economic development affect the ability to protect against environmental threats, and environmental degradation influences economic development, weakening its potential. According to UN experts, environmental losses due to pollution exceed the cost of measures aimed at fighting it. In developing countries they are much larger than in developed states. Each year, from 0.5 to $2.5 \%$ of GNP is lost due to pollution, and the cost of measures that would radically reduce pollution in industrial countries accounts for 1-2\% of GNP.

Modern changes in international relations are exacerbated by factors that affect the security of both the individual state and the system of states. Firstly, environmental threats do not have the nature of targeted actions. They are only unintended consequences of environmental disasters or development processes. Secondly, environmental threats cannot be subject to international standards of border or state integrity. Environmental threats can cause tensions in international relations and bring about new types of conflict that cannot be settled even through joint military action. Conversely, their settlement becomes an element of interaction, bringing states and peoples closer.

Environmental threats that can disrupt international stability include massive migration of people from areas of natural and man-made disasters (such as droughts in East Africa or the Chornobyl disaster), and the enormous environmental damage caused by industrial emissions, forest degradation, extinction of biodiversity and finally climate change. Thus, the concept of security has significantly expanded. Security is becoming a comprehensive category that covers most of the challenges of protecting the population from all types of threats.

\section{SUMMARY}

Environmental threats are not clearly identifiable as cause - effect relationship, but they are quite closely interrelated and linked to other social, political and economic factors that also affect the security situation. 
Intensified fight for ownership and use of clean air, water, arable land, fisheries and food resources, once considered free, is now a real threat to regional security.

The consideration of the time factor is important in addressing environmental security, as these threats remain vitally important in the long run. Sixth, the ecological aspect of security covers the actual existing threats, as a result, the level of security of the state, region and the world as a whole becomes dependent on them. The better humanity is aware of the complex relationship between environmental conditions in different corners of the globe, the more serious it becomes in understanding the regional and even global effects of particular environmental changes. Solving environmental problems on a global scale requires concerted action of governmental and non-governmental organizations, cooperation between states and regions, and the development of long-term environmental policies. Therefore, environmental security is increasingly becoming an integral component of national and global security.

\section{REFERENCES}

1. Andreytsev V. Environmental Safety Law: Teaching and sciencepractical. tool / V.I. Andreytsev K. : Znannya-Press, 2002. 332 p.

2. Environmental risk and national security // Economy. Entrepreneurship. The environment. 1994. № 1. S. 20.

3. Economy, freedom, solidarity. [G. Hofman, V. Demetyev, N. Fedorenko. M. : Nauka, 1991. 304 p.

4. Great Interpretative Dictionary of Modern Ukrainian / ed. by V. Busel. K. : Irpin. Perun. 2002. 1440 p.

5. Interpretive Dictionary of Metrology, Measurement Engineering and Quality Management: Basic Terms. M., 1990.

6. Kachinsky A., Khmil G. Ecological security of Ukraine: analysis, forecast, evaluation and state policy / A. Kachinsky, G. Khmil. K. : NISD, 1997. $130 \mathrm{p}$.

7. Khlobystov E.V. Ecological security of transformation economy / E. Khlobystov: RVPS of Ukraine of NAS of Ukraine. - K. : Chornobylinterinform Agency. 2004. 336 p.

8. Lapina M. Ensuring of environmental security by law enforcement agencies: foreign experience: monograph / M.A. Lapina. - M. : VNII Ministry of Internal Affairs of Russia, 2001. 115 p.

9. Law of Ukraine "On National Security of Ukraine" of 21 June 2018 // Verkhovna Rada of Ukraine Bulletin, 2018, No. 31, Art. 241.

10. Law of Ukraine "On Objects of High Danger" of January 18, 2001. 73; 2003, No. 30, Art. 247. 
11. Law of Ukraine "On Environmental Protection" of June 25, 1991. The Verkhovna Rada of Ukraine Bulletin, 1991, No. 41, Art. 546.

12. Law of Ukraine "The Main Principles (Strategy) of State Ecological policy of Ukraine for the Period up to 2030" of February 28, 2019. Verkhovna Rada of Ukraine Bulletin, 2019, No. 16, Art.70.

13. Mahmud A.A. Environmental safety as a subject of international cooperation policy: $\mathrm{PhD}$ reference paper: 23.00 .02 / A.A. Mahmoud: Inst. of State and Law. V.M. Koretskiy NASU. K., 2000. 24 p.

14. Malyshko MI Environmental Law of Ukraine: Educ. tool. K. : Yuridichna Kniga Publishing, 2001. 389 p.

15. National Security of Ukraine: History and Present / Ed. O. Goncharenko. K., 1993. 82 p.

16. Serov G. Legal regulation of issues of environmental security in industrial and other activities / G. Serov. Moscow: Os-89, 1998. 222 p.

17. Skakun O. Theory of State and Law: textbook / O. Skakun: trans. from Rus. Kharkiv: Consum, 2001.656 p.

18. State standard of Ukraine. Safety of industrial enterprises. Terms and definitions. DSTU 2156-93. K., 1994.

19. Philosophical Encyclopedic Dictionary / [Ed.: S. Averintsev, E. ArabOgly, L. Ilyichev et al.]. 2nd ed. M. : Soviet Encyclopedia. 1989. 815 p.

20. Vedenin N. Environmental Law: Textbook. [for university students ] / Vedenin N.N. M. : Law. 2000. 336 p. 20.

21. Yurkevich Pamphil. History of Philosophy of Law. Philosophy of Law / Pamphil Jurkevich // Philosophical Diary. $2^{\text {nd }}$ ed. K : Editorial in the magazine "Ukrainian World", 2000. 769 p.

Information about the authors: Balyuk G.,

$\mathrm{PhD}$ (Law), Corresponding Member of the National Academy of Legal Sciences of Ukraine, Professor at the Ecological Department, Kyiv National T. Shevchenko University 60, Volodymyrska str., Kyiv, 01033, Ukraine

ORCID: 0000-0001-5855-0142

Kovalchuk T., $\mathrm{PhD}$ (Law), Associate Professor, Head of Ecological Law Department, Kyiv National T. Shevchenko University 60, Volodymyrska str., Kyiv, 01033, Ukraine

ORCID: 0000-0003-0157-2767 